\title{
Persepsi Dosen Pembimbing Klinik Dalam Pelatihan Pemberian Umpan Balik Dengan Metode Pendleton Kepada Mahasiswa
}

\author{
Perception of Clinical Supervisor in Giving \\ Feedback Training With Pendleton Methods to \\ Students
}

\author{
Nyka Dwi Febria ${ }^{1}$, Mora Claramita ${ }^{2}$ Widyandana $^{3}$ \\ ${ }^{1}$ Medical Education Departement of Dentistry, Medical \\ and Healt Science Faculty UMY \\ 2,3 Department of Medical Education, Faculty of \\ Medicine, Gadjah Mada University \\ Korespondensi : nica_dentist@yahoo.com
}

\begin{abstract}
Abstrak:
Latar belakang: Umpan balik sangat dibutuhkan dalam pendidikan sarjana dan pendidikan klinik. Umpan balik yang diberikan didalam pendidikan klinik digunakan untuk memberikan penguatan atas tindakan yang dilakukan atau memberikan koreksi terhadap kesalahan yang dilakukan dalam melakukan suatu tindakan perawatan kepada pasien. Umpan balik yang diberikan oleh dosen bervariasi antara satu dosen dengan dosen yang lainnya. Sehingga diperlukan pelatihan untuk pemberian umpan balik tersebut. Tujuan: Tujuan dari penelitian ini adalah untuk memberikan pelatihan pemberian umpan balik dosen pembimbing klinik kepada mahasiswa. Metode: Jenis penelitian ini adalah penelitian kuasi eksperimental. Subyek penelitian terdiri dari 32 dosen yang memenuhi kriteria inklusi, yang terdiri dari dokter gigi umum sebayak 25 orang, dokter gigi spesialis sebanyak 3 orang, dan dokter gigi S2 sebanyak 4 orang. Hasil: 96,6\% menyatakan siap untuk memberikan umpan balik kepada mahasiswa setelah mengikuti pelatihan, pertanyaan kedua menyatakan waktu untuk pelatihan cukup sebesar $84,4 \%$, pertanyaan ketiga menyatakan pelatihan umpan balik yang diberikan merupakan hal yang baru sebesar 84,4\%, pertanyaan keempat menyatakan materi umpan balik dengan metode Pendleton merupakan hal yang baru sebesar $100 \%$, dan pertanyaan kelima menyatakan materi yang diberikan cukup lengkap sebesar 96,9\%. Kesimpulan: Pelatihan pemberian umpan balik dengan metode Pendleton kepada dosen pembimbing klinik di kedokteran gigi memberikan pengalaman dan pengetahuan yang baru untuk digunakan dalam pembimbingan fase klinik kepada mahasiswa.
\end{abstract}

Kata kunci: pelatihan umpan balik, dosen pembimbing klinik, pendleton

\begin{abstract}
:
Feed back is necessary in undergraduate degree and clinical program. In clinical program, the feed back is given in order to affirm procedure which had been done or correcting an error when patient is treated. The feed back given may vary betwen one supervisor dentist to another. Therefore, a training is needed for assessing the feed back. Purpose: The purpose of this study was to give a feed back training from clinical supervisor to clinical student. Method: The type of study was a quasi-
\end{abstract}


Nyka Dwi Febria, Mora Claramita, Widyandana | Persepsi Dosen Pembimbing Klinik dalam Pelatihan Pemberian Umpan Balik dengan Metode Pendleton kepada Mahasiswa

experimental. The subject of the study consists of 32 supervisors who fulfill inclusion criteria. The 32 subjects consist of 25 general practitioner dentists, 3 specialist dentists, and 4 general practitioner dentist who had taken master degree. Results: result of this study was 96,6\% of subjects declare that they are ready to give feed back to clinical student after join the training, second question showed that $84,4 \%$ of the subjects declare that time given for training is sufficient, third question showed that $84,4 \%$ subjects declare that feed back training which given was a new material, fourth question showed that 100\% subjects declare that feed back material using Pendleton method was new thing and fifth question showed that 96,6\% of subjects declare that the material given is comprehensive. Conclusion : The training for assesing feed back using Pendleton method for clinical supervisor dentists in dental school gives new experience and knowledge to be implemented in clinical advisory phase to clinical student.

Keyword: giving feedback training, clinical supervisor, pendleton

\section{Pendahuluan}

Pendidikan mahasiswa kedokteran gigi pada fase klinik diperlukan bimbingan dari dosen. Pembimbingan tersebut dilakukan di klinik ketika mahasiswa melakukan tindakan kepada pasien. Pembimbingan dilakukan dengan pemberian umpan balik terhadap tindakan mahasiswa. Salah satu komponen penting dalam pembimbingan klinik adalah pemberian umpan balik kepada mahasiswa oleh dosen ${ }^{1}$. Pembelajaran klinik memberikan pengalaman bagai mahasiswa untuk berinteraksi secara langsung kepada pasien. Pengamatan dilakukan oleh dosen pembimbing klinik selama mahasiswa mengerjakan tindakan kepada pasien. Pengamatan tersebut digunakan untuk memberikan umpan balik yang efektif dalam hal kelebihan dan kekurangan yang dilakukan oleh mahasiswa ${ }^{2}$. Umpan balik yang diberikan dosen pembimbingan klinik diharapkan positif sehingga dapat meningkatkan keterampilan mahasiswa dalam melakukan perawatan kepada pasien. Umpan balik yang positif tersebut dapat dilakukan dengan berbagai variasi penyampaian. Salah satu metode yang digunakan adalah Pendleton. Metode Pendleton digunakan karena terjadi interaksi dua arah antara dosen dan mahahasiswa. Mahasiswa dapat mengambil hal-hal baik yang sudah dilakukan dan mengkoreksi hal-hal yang kurang selama melakukan perawatan kepada pasien. Sedangkan dosen pembimbing klinik diharapkan dapat memperkuat keterangan yang disampaikan oleh mahasiswa dengan menambahkan umpan balik yang sesuai dengan tindakan yang dilakukan oleh mahasiswa ${ }^{3}$. Berdasarkan fakta-fakta diatas penulis ingin melakukan pelatihan pemberian umpan balik kepada dosen pembimbing klinik sehingga diharapkan dapat memberikan manfaat dalam pemberian umpan balik kepada mahasiswa.

\section{Metode}

Penelitian ini adalah penelitian quasi eksperimental dengan metode post test design. Subyek penelitian adalah semua dosen pembimbing klinik kedokteran gigi Institut Ilmu Kesehatan (IIK) Bhakti Wiyata Kediri. Kriteria inklusi responden pada penelitian ini adalah dosen pembimbing klinik dan bersedia menjadi responden dengan mengisi lembar persetujuan mengikuti pelatihan dari tahap awal hingga akhir. 
Kriteria ekslusi dalam penelitian ini dosen pembimbing klinik yang tidak mengikuti jalannya penelitian. Terdapat 55 orang dosen kedokteran gigi IIK Bhakti Wiyata Kediri. Dosen yang mengikuti pelatihan sebanyak 32 orang dosen. Sebanyak 23 dosen yang lainnya sedang dalam masa studi dan berhalangan hadir sehingga dikeluarkan (drop out). 32 orang dosen terdiri dari dokter gigi umum sebayak 25 orang, dokter gigi spesialis sebanyak 3 orang, dan dokter gigi S2 sebanyak 4 orang. Pengumpulan data diawali dengan memberikan pengarahan tentang jalannya penelitian dan memberikan lembar persetujuan tindakan mengikuti penelitian. Kemudian dosen diberikan modul dan materi tentang umpan balik dengan metode Pendleton yang dimodifikasi oleh pakar. Pemberian umpan balik kepada mahasiswa dipraktekkan secara langsung oleh dosen pembimbing klinik selama 4 hari. Dosen Tabel 1. Persepsi Pelatihan diberikan kuesioner penelitian setelah selesai dilakukan pelatihan. Persepsi dosen pembimbing klinik diukur dari kuesioner yang disebarkan pada akhir pelatihan pemberian umpan balik terstruktur dengan metode Pendleton yang dimodifikasi. Kuesioner tersebut terdiri dari 5 pertanyaan tertutup dan 3 pertanyaan terbuka.

\section{Hasil}

Data diambil dari dosen pembimbing klinik sebanyak 32 orang. Persepsi dosen pembimbing klinik terhadap pelatihan yang diberikan diukur dari kuesioner yang disebarkan pada akhir pelatihan pemberian umpan balik terstruktur dengan metode Pendleton yang dimodifikasi. Kuesioner tersebut terdiri dari 5 pertanyaan tertutup dan 3 pertanyaan terbuka.

\begin{tabular}{|c|c|c|c|c|c|c|}
\hline \multirow{2}{*}{ No } & \multirow{2}{*}{ Keterangan } & \multicolumn{2}{|c|}{$\mathrm{Ya}$} & \multicolumn{2}{|c|}{ Tidak } & \multirow{2}{*}{ Keterangan } \\
\hline & & $\mathrm{N}$ & $\%$ & $\mathrm{~N}$ & $\%$ & \\
\hline 1 & $\begin{array}{l}\text { Setelah mengikuti pelatihan ini, } \\
\text { apakah Anda sudah merasa siap } \\
\text { untuk memeberikan umpan balik } \\
\text { terstruktur dengan model Pendleton } \\
\text { yang dimodifikasi kepada } \\
\text { mahasiswa? }\end{array}$ & 31 & 96,9 & 1 & 3,1 & \\
\hline 2 & $\begin{array}{l}\text { Apakah waktu yang diberikan untuk } \\
\text { memberikan seluruh materi } \\
\text { pelatihan sudah cukup? } \\
\text { Bila tidak, berapa waktu yang Anda } \\
\text { rasa cukup? }\end{array}$ & 27 & 84,4 & 5 & $\begin{array}{l}15, \\
6\end{array}$ & $\begin{array}{l}\text { 1. } 3 \text { hari } \\
\text { 2. } 2 / 3 x \text { pertemuan } \\
\text { 3. } 1 \text { hari setiap bulan } \\
\text { secara kontinyu } \\
\text { 4. } 1 \text { minggu } \\
\text { 5. Praktek di } \\
\text { keseharian, karena } \\
\text { kondisi mahasiswa } \\
\text { berbeda }\end{array}$ \\
\hline 3 & $\begin{array}{l}\text { Apakah materi umpan balik yang } \\
\text { diberikan pada pelatihan merupakan } \\
\text { hal yang baru bagi Anda? }\end{array}$ & 27 & 84,4 & 5 & $\begin{array}{l}15, \\
6\end{array}$ & \\
\hline
\end{tabular}


Nyka Dwi Febria, Mora Claramita, Widyandana | Persepsi Dosen Pembimbing Klinik dalam Pelatihan Pemberian Umpan Balik dengan Metode Pendleton kepada Mahasiswa

\begin{tabular}{|c|l|l|l|l|l|l|}
\hline 4 & $\begin{array}{l}\text { Apakah materi pemberian umpan } \\
\text { balik dengan metode Pendleton } \\
\text { yang dimodifikasi merupakan hal } \\
\text { yang baru bagi Anda? }\end{array}$ & 32 & 100 & 0 & 0 & \\
\hline 5 & $\begin{array}{l}\text { Menururt Anda, Apakah materi } \\
\text { yang diberikan pada pelatihan ini } \\
\text { sudah lengkap? } \\
\text { Bila tidak, materi apa yang } \\
\text { sebaiknya ditambahkan? }\end{array}$ & 31 & 96,9 & 1 & 3,1 & $\begin{array}{l}\text { Memancing self } \\
\text { asessment mahasiswa } \\
\text { kurang }\end{array}$ \\
\hline
\end{tabular}

Kuesioner persepsi pelatihan terdiri atas 5 pertanyaan tertutup. Hal yang dievaluasi mengenai persepsi dosen pembimbing klinik terhadap pelatihan pemberian umpan balik dengan metode Pendleton yang dimodifikasi. Pertanyaan pertama menyatakan $96,6 \%$ menyatakan siap untuk memberikan umpan balik kepada mahasiswa setelah mengikuti pelatihan, pertanyaan kedua menyatakan waktu untuk pelatihan cukup sebesar $84,4 \%$, pertanyaan ketiga menyatakan pelatihan umpan balik yang diberikan merupakan hal yang baru sebesar $84,4 \%$, pertanyaan keempat menyatakan materi umpan balik dengan metode Pendleton merupakan hal yang baru sebesar $100 \%$, dan pertanyaan kelima menyatakan materi yang diberikan cukup lengkap sebesar $96,9 \%$.

Pertanyaan kedua tentang waktu pelatihan, 5 orang menyatakan kurang $(15,6 \%)$ dan mereka menyarankan agar pelatihan 2 sampai 3 kali pertemuan, 1 hari setiap bulan secara kontinyu, 1 minggu, praktek di keseharian. Pertanyaan kelima tentang materi yang diberikan pada pelatihan pemberian umpan balik, 1 orang menyatakan kurang, diperlukan penambahan point memancing self asessment mahasiswa. Pertanyaan no 6-8 dari evaluasi peserta merupakan pertanyaan terbuka. Pertanyaan ke enam yang paling disukai pada pelatihan pemberian umpan balik adalah menambah pengetahuan tentang umpan balik (44\%), strategi penyampaian materi $(44 \%)$, bahan evaluasi diri (dosen) (9\%) dan pembicara $(3 \%)$.

Pertanyaan ke tujuh tentang yang tidak disukai pada pelatihan pemberian umpan balik ini adalah kurang adanya contoh berupa interaksi terhadap mahasiswa secara langsung (10\%), penataan ruangan dan sarana prasarana $(9 \%)$, role play $(6 \%)$, materi yang terlalu banyak dalam waktu yang singkat (9\%) dan tidak ada atau suka dengan pelatihan ini $(66 \%)$.

Pertanyaan kedelapan tentang masukan dan saran dalam penelitian ini adalah menambah praktek dan pelibatan mahasiswa secara langsung (31\%), pelatihan dilakukan secara rutin dan waktu ditambah (31\%), tidak ada masukan dan saran $(25 \%)$ dan penataan ruang dan sarana prasarana (13\%).

\section{Pembahasan}

Penelitian ini bertujuan untuk memberikan pelatihan umpan balik dosen pembimbing klinik kepada mahasiswa. Dampak yang diharapkan pada pelatihan adalah dapat memberikan pengalaman kepada dosen pembimbing klinik untuk dapat memberikan umpan balik kepada 
mahasiswa dengan baik. Hasil penelitian didapatkan bahwa 96,6\% menyatakan siap untuk memberikan umpan balik kepada mahasiswa setelah mengikuti pelatihan. Kesiapan dosen pembimbing klinik dalam memberikan umpan balik kepada mahasiswa sangat dibutuhkan untuk dapat membimbing mahasiswa dalam pendidikan klinik. Teori operant conditioning mengatakan bahwa memasukkan unsur penguatan (reinforce) maka akan memperkuat respon yang akan ditimbulkan ${ }^{4}$. Penguatan pada pelatihan diberikan ketika narasumber memberikan masukan terhadap umpan balik yang dilakukan oleh dosen pembimbing klinik.

Pertanyaan kedua menyatakan waktu untuk pelatihan cukup sebesar $84,4 \%$, waktu yang digunakan untuk pelatihan dalam penelitian ini 5 hari dengan pemberian materi dan penjelasan modul dari pakar selama 1 hari. Sedangkan 4 hari dosen pembimbing klinik memberikan umpan balik dengan metode Pendleton yang dimodifikasi secara langsung kepada mahasiswa dengan pengamatan dari peneliti.

Umpan balik merupakan informasi yang diberikan secara spesifik terhadap suatu tindakan yang dilakukan dibandingkan dengan teori yang sudah ditetapkan sebagai suatu acuan untuk tindakan tertentu ${ }^{5}$. Pertanyaan ketiga menyatakan pelatihan umpan balik yang diberikan merupakan hal yang baru sebesar $84,4 \%$. Dari hasil pelatihan tersebut memberikan hasil bahwa dosen pembimbing klinik memerlukan pelatihan untuk dapat memberikan umpan balik kepada mahasiswa. Sehingga pelatihan tersebut dapat meningkatkan performa mahasiswa dalam melakukan tindakan medis kepada pasien. Performa kilnik mahasiswa dapat meningkat dengan adanya umpan balik yang diberikan tersebut ${ }^{6}$. Perbaikan terhadap suatu tindakan medis kepada pasien dengan berdasarkan prosedur yang ada membutuhkan suatu umpan balik dari dosen pembimbing klinik untuk dapat meningkatkan kualitas kerja mahasiswa? .

Pertanyaan keempat menyatakan materi umpan balik dengan metode Pendleton merupakan hal yang baru sebesar $100 \%$. Umpan balik dengan model Pendleton mempunyai 4 langkah yaitu a) mahasiswa mengatakan perfoma baik yang sudah dilakukan, b) dosen pembimbing klinik menyetujui dan mengeksplorasi performa yang baik tersebut, c) mahasiswa mengatakan performa yang kurang dan yang diperlukan perbaikan, d) dosen pembimbing klinik mengatakan hal-hal yang diperlukan perbaikan. Penelitian ini memodifikasi dengan menambahkan 1 langkah yaitu berupa rencana aksi yang akan dilakukan untuk lebih meningkatkan hasil kinerja mahasiswa. Motode Pendleton memiliki kelebihan berupa memberikan kesempatan kepada mahasiswa untuk menilai kelebihan dan kekurangan yang dilakukan oleh mahasiswa $^{3}$. Kelebihan ini dapat mendorong mahasiswa untuk dapat menilai hasil kinerja yang dilakukan. Sehingga diharapkan mahasiswa akan lebih memahami tindakan yang dilakukan.

Pertanyaan kelima menyatakan materi yang diberikan cukup lengkap sebesar 96,9\%. Materi diberikan berupa penjelasan dari pakar tentang umpan balik, pemberian modul sebagai pedoman untuk melakukan umpan balik, dan dosen melakukan umpan balik secara langsung kepada mahasiswa yang dilakukan selama 4 hari. Pelatihan penggunaan umpan balik dengan metode pendleton selama 4 hari tersbut akan mendorong terjadinya meaningful learning dengan pengetahuan yang telah dimiliki sebelumnya (prior knowledge) peserta, sehingga menghindari miscoception ${ }^{4}$. 
Nyka Dwi Febria, Mora Claramita, Widyandana | Persepsi Dosen Pembimbing Klinik dalam Pelatihan Pemberian Umpan Balik dengan Metode Pendleton kepada Mahasiswa

Keterbatasan dalam penelitian ini adalah pelatihan yang diberikan umpan balik secara langsung oleh pakar, tidak adanya role play simulasi kepada mahasiswa sesungguhnya dengan berbagai karakter mahasiswa yang berbeda-beda dikarenakan keterbatasan waktu yang ada dan waktu pelaksanaan pelatihan yang pendek sehingga kurang memberikan kesempatan untuk peserta dalam berlatih memberikan umpan balik.

\section{Simpulan}

Berdasarkan hasil penelitian dan pembahasan, maka dapat diambil kesimpulan bahwa pelatihan pemberian umpan balik diperlukan untuk dapat memberikan pengalaman kepada dosen pembimbing klinik dalam memberikan umpan balik terhadap pekerjaan mahasiswa. Metode Pendleton merupakan pengetahuan baru yang didapatkan dalam pelatihan ini. Metode ini memberikan kesempatan untuk mahasiswa mengemukakan kelebihan dan kekurangan dalam tindakan yang dilakukan. Tugas dari dosen pembimbing klinik memberikan penguatan atas tindakan hal yang dilakukan dan diungkapkan mahasiswa.

\section{Saran}

Berdasarkan hasil penelitian dan kesimpulan diatas, maka dapat diajukan beberapa saran yaitu:

1. Dapat dilakukan pelatihan dengan melibatkan mahasiswa secara langsung dengan dipandu oleh pakar.

2. Dapat dilakukan penelitian lebih lanjut untuk dilakukan penilaian pemberian umpan balik di dalam pendidikan klinik.

\section{Daftar Pustaka}

1. Hesketh EA, Laidlaw JM, Developing the teaching instinct: 1:feedback. Med Teacher. 2002;24:245-8.

2. Branch, W.T \& Paranjape, A. 2002. Feedback and reflection: teaching methods for clinical settings. Academic Medicine. Vol.77:11851188

3. Cantillon, P. \& Sargeant, J. 2008. Giving feedback in clinical settings. BMJ (Clinical research ed.), pp. 12921294

4. Ormrod, J.E., 2012. Human Learning 6th ed., New Jersey: Pearson

5. Van de Ridder, J.M.M., Stokking, K.M., McGaghie, W.C., Cate, O.T.J. 2008. What is feedback in clinical education?. Medical education. p. 189-197

6. Veloski, J., Boex, J.R., Gasberger, M.J., Evans, A., Wolfson, D.B. 2006. Systematic review of the literature on assessment, feedback and physicians' clinical performance: BEME Guide no 7. Medical Teacher 28, 2, pp 117128

7. Grantchrov, T.P \& Reznick, R.K. 2008. Teaching procedural skills. Universiti of Toronto 